\title{
Changes of Employment in Enterprises in the South-Moravian Region during and after Economic Recession
}

\section{Svobodová Hana}

\begin{abstract}
In the period 2008-2010, the labour market of the European Union was significantly affected by the economic recession, which impacted economic development in all regions of the Czech Republic including the South Moravian Region. Impacts of the economic recession in the labour market were primarily reflected on decline of vacant work places, an increase in job seekers, and thus an increase in the unemployment rate, as well as an increase in long-term unemployment, etc. Enterprises in the region are responding to this situation in different ways, but all have to flexibly adapt - increase or decrease - the number of employees and production as movements in the labour market have been very significant for the past four years. In 2011 and 2012, the economic recession was not discussed anymore. However, has it already finished? The analysis of movements in the labour market, especially comparison of plans and reality in enterprises during and after economic recession is the aim of the paper.
\end{abstract}

Key words: labour market, employment, unemployment, processing industry, South Moravian region, recession

\section{INTRODUCTION}

Since mid-2006, the world economy experienced a robust growth. Unemployment in many parts of the world dropped to historic lows. However, since about mid-2007, an attenuation incoming to the real estate market began to be clearly evident. It also brought concerns to financial markets. There were worries what impacts the increasingly worse repayment mortgages would have. In late 2007 it was clear that the U.S. credit crisis was worse than expected and increased the likelihood of recession in the U.S., which further deepened already at the end of the year and especially during 2008 and its impacts were reflected in all economic indicators, including situation in the labour market (according to "Czech Statistical Office," 2011). This recession gradually spread to all developed countries in the world.

In the Czech Republic, the impacts of the economic recession were reflected on the economy around the middle of 2008 and the deteriorating labour market development can be traced since the second half of 2008 (Toušek et al. 2009; Toušek \& Novák, 2010, in Slovakia e.g. Lauko, Križan, and Gurňák 2009). The situation in the labour market changed rapidly between 2008 and 2009. There was a sharp decrease in the number of vacant work places and an increase in the number of job seekers, thus the unemployment rate increased.

\subsection{Theoretical Background}

In the last few years, studying the impacts of the recession on the economy and the labour market did not come into the fore of the economic-geographical research only in the Czech Republic but also abroad. However, most of these researches are oriented on macroeconomic level; fewer 
authors are interested in situation on labour market at regional or even microregional level (e.g. Fang Cai, Dewen Wang, and Yang Du 2002, Gora \& Lehmann 1995, Broersma \& van Dijk $2005 \ldots .$.$) . This situation is caused by lack of data on lower hierarchical levels.$

Smith and Swain (2010) analysed mainly financial data and economic vulnerabilities of Central European countries. Similarly analyse fiscal policies Fikret (2012) who claims that a remedy for getting out of the economic crisis (also crisis on labour market) in the Balkan region is not a restrictive fiscal policy, but increased cross-border cooperation based on joint investment projects. Klinger \& Rothe (2010) were interested in the situation in Germany, especially in the influence of the government decisions on the development of unemployment. This analysis is very important for the labour market in the Czech Republic, since the situation in the German markets most influence the economic situation in the Czech Republic. Case studies of other European countries (except Germany also Great Britain, Denmark and Spain) were carried out by Leschke \& Watt (2010). We can find parallels in the factors affecting the labour market in the Czech Republic, too, and measures which should be more emphasized on the Czech labour market - particularly the flexibility of the labour market with higher number of part-time jobs. The options how to achieve greater flexibility include the so-called "work sharing" - sharing jobs, "wage flexibility" - greater flexibility of wages, one of other considered options is the option of support early retirement, etc. The impact of the economic crisis is also evident in discrepancy in offer and demand of employee's structure - especially graduates, where offer is not adequate (Barakat et al. 2010). Therefore, specific measures applied by the government at the central level through ministries in direct cooperation with regional governments should focus in this direction as well. This requires having a good strategy which should have specific practical impacts. Other scientific studies pay attention to social consequences of economic recession on labour market, such as migration but also vulnerability of employment (Chowdhury, Islam, and Lee 2013). Domínguez-Mujica, Guerra-Talavera, and Parreño-Castellano (2012) offer an initial assessment of the impact of the economic crisis on Spain's migration flows. The Spanish government similarly to South-Moravian Labour Office has adopted various measures to restrict the arrival of new immigrants: it has reduced work permit quotas and it has modified the Foreign Residents Law, toughening residence permit requirements.

Despite the negative development reflected in the labour market, number of experts speaks of a slow unwinding of the economic recession (e.g. Rojíček 2010, Singer 2011), which was evident from selected statistical indicators (e.g. GDP, see below). Some authors (Akyüz 2011) speculate that the recession may be over but thinks where it could strike next. In 2011, nevertheless, the situation in the labour market was not different from the previous years in many aspects. However, the labour market reacts to the economic development always with a certain delay, which corresponds with results of a survey of employment in the South Moravian Region, which was conducted for the tenth time in 2012 and serves as an important source of information about the development of the employment in the South Moravian region. The question still remains the stability of the global markets (and thus in labour markets as well), which are very sensitive to even the slightest changes in individual economies (e.g. the Euro zone crisis). 


\section{AIMS AND METHODS}

When analyzing the changing situation in the labour market, it is needed to evaluate both changes in employment (Fišer, Toušek, and Janota 2008), in particular the situation of the industry (Pavlínek \& Ženka 2010) as well as services which have gone through a dynamic evolution in the last two decades (Maryáš et al. 2006, Szczyrba et al. 2005), and the development in unemployment.

The survey of employment in enterprises in the South Moravian Region from 31/12/2011 (Svobodová et al. 2011), which was realized by South Moravian contact points of the Labour Office of the Czech Republic in collaboration with the Regional Development Department of the South Moravian Regional Authority, is a unique study which analyzes the evolution of the labour market. The last one was conducted during January and February 2012. The aim of this investigation was to characterize in detail the structure of the labour force in the South Moravian Region, to capture changes in employment which annually take place in the South Moravian Region, and - which is important for the paper - to characterize development of the labour market in the South Moravian Region and expectation on labour market until the end of the following year, including the intentions of employers in hiring and laying off employees in individual profession. Using the survey - unique data about the employment and the structure of workers in companies, which cannot be detectable in any other way and are not available for any other region in the Czech Republic - are evaluated by the author. At the same time it is the only the survey which goes to the lower level (municipality) and has a practical usage for the region while taking decisions, unlike the sample survey of the labour force carried out by the Czech Statistical Office (CSO) with data validity to the regional level and loaded by the statistical deviation.

Every year, a database of companies with a variety of employment data is compiled (e.g. structure of employees by sex, highest level of education, according to ISCO categories of employment and the number of employed foreigners, number of agency employees, number of people employed in part-time jobs, etc.). For the purposes of this contribution, which aims to analyze the reality and visions about the development of employment in enterprises during and after the recession (2008-2011), 1,539 enterprises collaborated in a questionnaire survey in 2008, 2009, 2010 and 2011 (number of enterprises was obtained by comparing entrepreneurs from databases of individual years, enterprises which have not filled in the questionnaire every year, were excluded). Representativeness of the data for the four observed years in terms of the employment structure by the basic sectors of the national economy in South Moravia (comparison of the employment data obtained from the survey from 31/12/2011 and data from the Labour Force Sample Survey (LFSS) in the 4th quarter of 2011) showed that $29.1 \%$ of all employed people in the county were included.

Due to the extensiveness of the data set and possibilities of their evaluation, increased attention will be paid to the secondary sector and construction, where $29.2 \%$ of all employed people in the county were included within the employment survey.

Besides the main objective of the contribution - analysis and comparison of the real and probable trend in the development of employment during the economic recession, including an assessment of supply and demand in terms of the profession of employees - a sub-goal was specified: analysis of employment and unemployment in the South Moravian Region in the period 
2008-2011 and comparison with the situation in the national level.

Following the objective of the paper, the following hypotheses were defined: "The expectations of employers in the South Moravian Region during the economic recession (2008$2010)$ were pessimistic in all sectors of the national economy, in the following years (2011, 2012) the expectations of employers are more optimistic and the number of workers employed in the enterprises will increase. In terms of the industries, demand for highly skilled workers will increase."

\section{RESULTS: SITUATION IN THE LABOUR MARKET IN THE SOU- TH MORAVIAN REGION}

\subsection{Employment}

In the course of the economic transformation in the 1990s, there were significant changes of the labour force among individual sectors and industries (Kunc \& Toušek 2001, Viturka et al. 2000). In the following years, these changes were much smaller. Since the end of 2008 , the economic recession became a significant factor which had a significant influence on the changes in the labour market (employment - moves among sectors of the national economy and individual industries - and unemployment).

The data from the Labour Force Sample Survey (LFSS) show that the number of employed people in the South Moravian Region significantly decreased by 14.7 thousand between 2008 and 2009 (Tab. 1). In 2010, however, there was a turnover and the number of employed people increased again (by 6.6 thousand to 533.7 thousand). However, in 2011, when the recession was not talked about any more, the number of employed people decreased again, though not as significantly as between 2008 and 2009 .

However, development in individual sectors was not the same: the number of workers in the primary sector did not change in the observed period. There is not much space for significant changes as the number of agricultural workers is on minimal level. Employment in the second sector of the economy grew, according to LFSS, continuously until the end of 2007; during 2008, however, it slightly decreased (by 2.2 thousand) and another, much more significant decrease in the number of people employed in the secondary sector was in 2009 (by 34.6 thousand persons between two years, i.e. $15.6 \%$ !). In 2010, the number of employed people increased by 6.5 thousand. The positive trend, however, was not confirmed in the following year. In the secondary sector in the South Moravian Region, the situation of workers in industry and construction developed differently. Employment in the industry increased until 2007, during the year 2008 , however, the number of employees in the industry decreased (by 2.1 thousand) and even a sharper decrease occurred in 2009 - according to the LFSS, industry lost a total of 36.0 thousand workers. In 2010 a turnover occurred again, compared to the previous year, and number of employees in the industry increased by 15.6 thousand, but in 2011 there was a decline again (by 2.5 thousand). Number of workers in the construction industry increased by 1.4 thousand (i.e. $2.5 \%$ ) in 2009, but in 2010 there was, mainly due to the effects of the economic recession and a slowdown in construction, a significant decrease in the number of workers, by 9.1 thousand $(16 \%)$. Despite a slight recovery in construction in 2011, the number of employees continued to 
drop. On the contrary, the tertiary sector grew significantly (by 22.1 thousand persons) during 2009, this year the maximum after the peak in 1989 was reached in the terms of the number of employees and then it decreased slightly in 2010 as in 2011, mainly due to dismissals of public administration workers, which occurred within personnel and payroll savings expected for 2011.

Tab. 1 - Structure of employment in the South Moravian Region by sectors (4th quarter 2008 2011, in thousands). Source: Employment and unemployment in Czech Republic according to the Labour Force Sample Survey for the 4th quarter of 2008, 2009, 2010, 2011, CSO Prague 2009, 2010, 2011, 2012

\begin{tabular}{|l|c|c|c|c|c|}
\hline $\begin{array}{l}\text { Sectors and indus- } \\
\text { tries }\end{array}$ & 2008 & 2009 & 2010 & 2011 & $\begin{array}{c}\text { Index } \\
2011 / 2008 \\
\text { (in \%) }\end{array}$ \\
\hline sector I & 15,5 & 13,3 & 14,8 & 15,5 & 100,0 \\
\hline sector II & 221,6 & 187,0 & 193,5 & 191,0 & 86,2 \\
\hline industry & 166,0 & 130,0 & 145,6 & 143,8 & 86,6 \\
\hline construction & 55,6 & 57,0 & 47,9 & 46,1 & 82,9 \\
\hline sector III & 304,6 & 326,7 & 324,2 & 322,8 & 106,0 \\
\hline In total & 541,8 & 527,1 & 533,7 & 529,3 & 97,7 \\
\hline
\end{tabular}

The secondary sector in the South Moravian Region showed, compared to the national average, similar numbers until the end of 2008, but in 2009 there was a significant reduction in the secondary sector at both levels, which was even more massive in the South Moravian Region. It was caused by the development of the industry, especially in manufacturing, where the number of employees at the end of 2009 made, based on the LFSS, less than a quarter of all employees in the county. This situation persisted both in the Czech Republic and the South Moravian Region in 2010 and 2011, but in both cases there was a slight increase in the share of employees in the secondary sector (by 0.8 percentage points - further only pp - in the South Moravian Region and by 0.3 pp in the Czech Republic).

In 2006, the tertiary sector in the South Moravian Region was more important for the employment than it was in the whole country, but in the following two years it declined below the national average. An important change came in 2009, when the share of the people employed in the tertiary sector increased to more than $60 \%$ and was significantly higher than the national average. In accordance with the development of other sectors, this situation continued in 2010, but both in the Czech Republic and in the South Moravian Region the tertiary sector share on the total employment dropped slightly.

The impacts of the economic recession can be also traced from other indicators, such as GDP (Fig. 1). GDP, as well as employment, showed a negative trend especially at the end of 2008 and during 2009; in 2010 there was a turnover and the number of employees in the individual sectors of the national economy increased again. During 2011, however, the positive trend was changed and the value of GDP was gradually declining. 


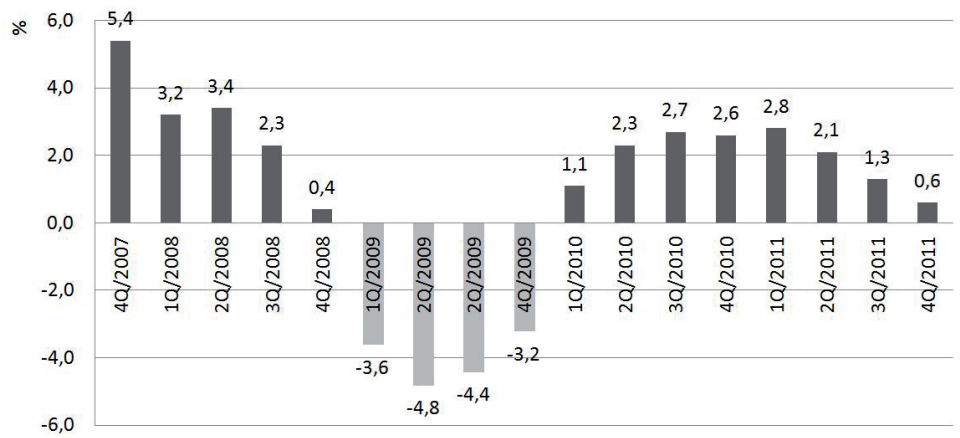

Fig. 1 - Annual growth of the real GDP in the Czech Republic (\%). Source: National Accounts, CSO Prague 2008-2011

\subsection{Unemployment}

Development of the labour market was very auspicious until 2008 (Fig. 2). At the end of this year, the Czech Republic and the South Moravian Region began to be impacted by the global economic recession, which became most evident in 2009 and, in the labour market, it continued in 2010, particularly in the first half of the year. In 2011, the situation improved slightly, in particular the rate of unemployment and the number of job seekers decreased, but the number of job vacancies is did not increase.

Negative impacts are reflected in the increase in the number of job-seekers, whose number increased by 22.9 thousand persons in the region between 2008 and 2009 (as at 31/12), i.e. by $53.1 \%$, which was the highest value registered since the beginning of the transformation of the Czech economy. At the national level, the number of applicants increased by 186.9 thousand (an increase by $53.1 \%$ as well). One of the impacts of the poor situation in the labour market was also a very low number of reported job vacancies. In the South Moravian Region there were recorded only a little over 3 thousand job vacancies at the end of 2009, which was a very low number. At the national level it was the lowest number in the last 10 years (less than 31 thousand job vacancies). There were 21.7 applicants for 1 vacancy in the county, the national average was slightly lower (17.4, but without the city of Prague it reached the value of 22.7 on average). The unemployment rate in the county exceeded the value of $10 \%$ and was 1.4 pp higher than the unemployment rate in the Czech Republic, which was the biggest difference in the entire observed period. The annual increase of the unemployment rate was by $3.8 \mathrm{pp}$, which was significantly higher than at the national level (3.2 pp). It can be said that the short-term positive development in the labour market, which was registered in 2006 and 2007, was significantly disrupted by the economic recession. The year 2009 can be described as the worst one since the beginning of economic transformation, in terms of the development in the labour market.

In 2010, the labour market in the South Moravian Region was still affected with the negative impacts of the economic recession, though the number of applicants and the unemployment rate did not grow so much as between the years 2008 and 2009. Though, the number of job seekers and the number of applicants per vacancy in the Czech Republic were the highest since 1989. 


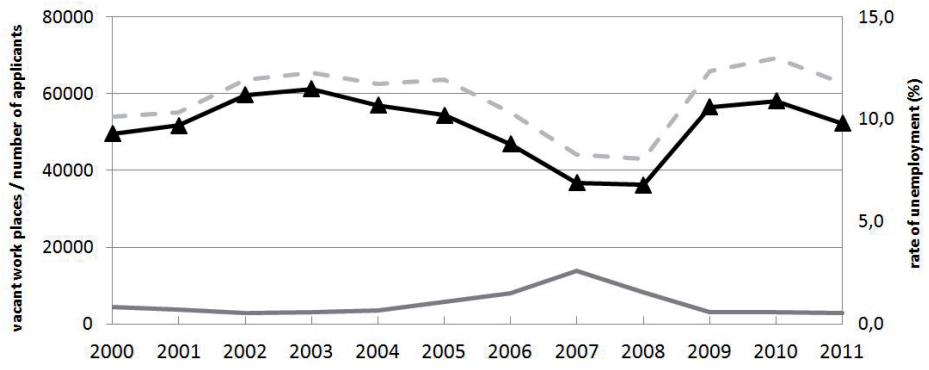

Vacant work places $\quad-\quad$ Number of applicants $\quad$ Rate of unemployment

Fig. 2 - Development of the number of job seekers and job vacancies in the South Moravian Region in 2000-2011 (as at 31/12). Source: Data of the Ministry of Labour and Social Affairs of the Czech Republic, own elaboration

The unemployment rate is very diverse in the South Moravian region (fig. 3). Especially the south of the region, the Znojmo and Hodonín districts, which are included among the areas with concentrated state support for the period 2010-2013, showed ones of the highest unemployment rates in the Czech Republic (the Hodonín district was with the unemployment rate of $14.5 \%$ the fourth worst among the districts at the end of 2011). Paradoxically, the Blansko district, which is also included among the regions with concentrated state support, had an average unemployment rate within the county and districts of the Czech Republic.

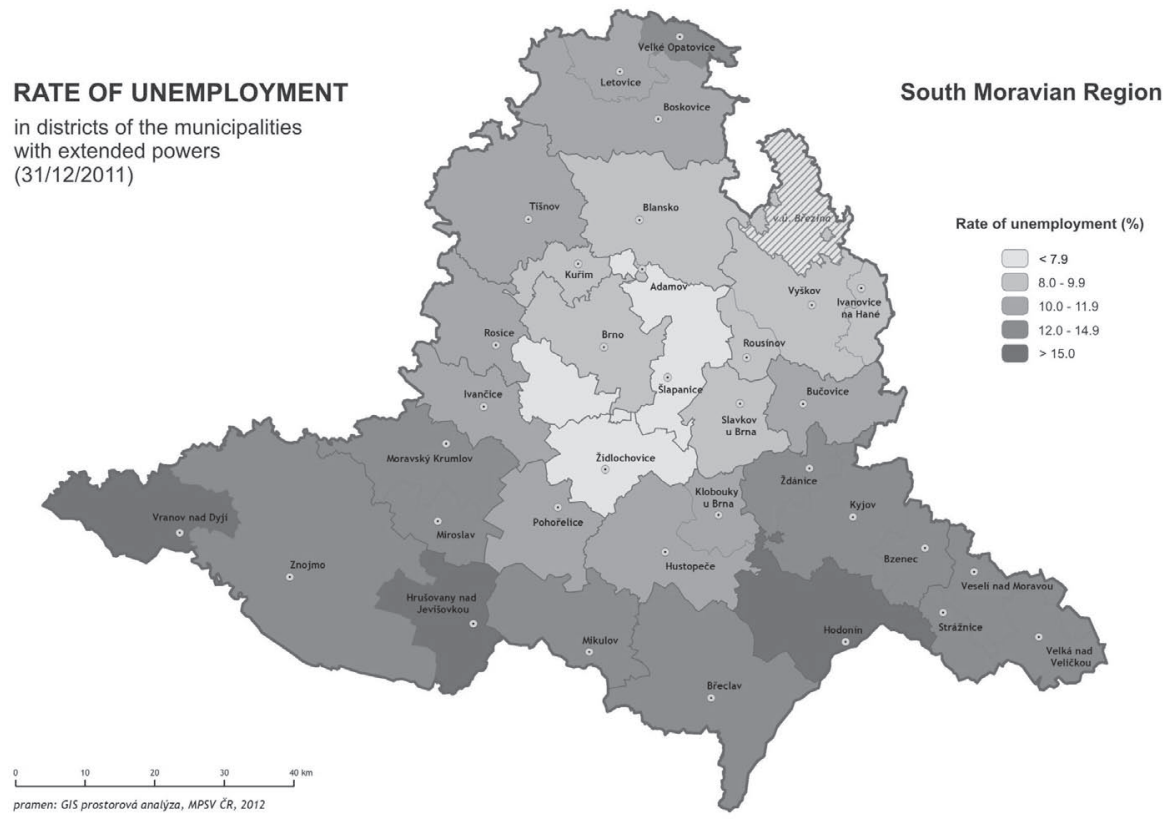

Fig. 3 - The unemployment rate in the territories of municipalities with commissioned local authority (as at 31/13/2011). Source: GIS spatial analysis, Ministry of Labour and Social Affairs, Prague 2012, own elaboration 


\subsection{Visions are reality of employment}

Survey of employment in enterprises in South Moravian Region detects the enterprises' plans in terms of number of employees for the following year. Every year, the actual number of employees as at 31/12 is ascertained and also plans to 31/12 of the following year, and within further investigation the current situation of employees is detected again. Based on these data, which were gained by comparing of enterprises, the visions and reality of the number of employees in each enterprise can be compared. Due to the extensiveness of the data and the inability to pay attention in detail to all sectors of the national economy at a small area, more attention will be paid to the processing industry. This restriction was also chosen for the possibility to compare the results of the processing industry with business cycle survey data from CSO.

Data from Labour Force Sample Survey also include information about domestic and foreign capital in enterprises. Similarly to Varum \& Barros Rocha (2011) who studied link between foreign ownership and employment, the Survey showed no significant differences between domestic and foreign firms in what concerns employment growth. The Survey additionally goes deeper into structure of sectors of national economy and even into branches of economy.

In the period of the economic recession (2008-2010), enterprises planned to rather decrease the number of employees in all the three sectors of the national economy. In the primary sector there was a greater decrease in the number of employees than expected (index of change between 2010 and 2008 was $79.5 \%$ ) and the primary sector continued to decline. Also in the secondary sector there were negative expectations of the future development, but the actual decline in the number of employees was always slightly lower (index of change $=87.8 \%$, fig. 4 ), to which a diversified structure of the industry in the county could help.

A very negative development was expected in the tertiary sector, but this premise was not fulfilled, which was mainly due to high share of public administration institutions in this sector (hospitals, schools, offices ...) which did not reduce the number of their employees too much. This trend was confirmed by index of change of $93.1 \%$.

In 2011, enterprises in the South Moravian Region showed positive development - the number of employees in the secondary and even tertiary sector increased slightly and further increase is expected by the end of 2012, too. In the primary sector there is occurring a continual decline, which is expected to continue.

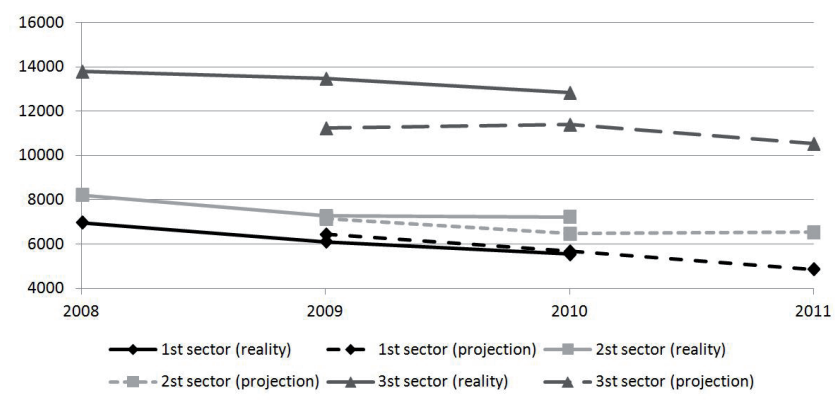

Fig. 4 - Actual number of employees in enterprises of individual sectors of the national economy as at 31/12/2008, 2009, 2010 and 2011 and number expected as at 31/12/2009, 2010, 2011 and 2012. Source: Questionnaire survey of the Labour Office in the South Moravian Region for years 2008, 2009, 2010 and 2011, own elaboration 
Development of the processing industry according to the survey of the employment in the South Moravian Region is displayed in fig. 5. The decline between the years 2008-2009 was expected especially in the production of furniture (by more than $30 \%$ ), in the food industry and glass industry (more than $20 \%$ ). In reality, however, the biggest decline occurred in the textile, clothing and leather industry (17.3\%), engineering (16.7\%), electronics (16.3\%) and metallurgy (15.7 $\%)$.

Between 2009 and 2010, the biggest decline in the number of employees was expected in the food industry which really occurred (decrease by $18.3 \%$ ), a significant decrease was expected in the glass and metallurgical industries and in all other industries as well. These premises were fulfilled in the glass industry (decrease by $9.0 \%$ ), a drop (by $8.5 \%$ ) also occurred in the textile and clothing industry. The only other sector in which the number of employees decreased was production of furniture (by $2.2 \%$ ). In other sectors there was an increase in the number of employees, mainly in the metalworking industry $(12.7 \%)$.

Overall, between 2008 and 2010, decrease of employees affected most the textile, clothing and leather industry, food and glass industry and the building materials industry (total decrease of the number of employees was more than $20 \%$ ). In contrast, the lowest decrease occurred in the wood processing industry (a decrease by only 1.6\%) and in the chemical and rubber industry (a decrease by $1.7 \%$ ).

Between 2010 and 2011, the biggest decline in employment was in the engineering industry (by $14.7 \%$ ), the expected decline, however, was originally even higher. In other industries there was no greater decrease in the number of employees. In many companies which expected decline, the number of employees increased, which may be one of the proofs of the subsiding economic recession. The biggest relative increase in the number of employees occurred in the glass industry (by $12.4 \%$ ), the engineering industry strengthened significantly as well (by $6.3 \%$ ).

Assumption about the number of employees in the county by the end of 2012 was positive for all sectors, except the paper and printing industry and electrical industry. Overall, according to the enterprises' expectations, reviving of the economy of the region can be expected.

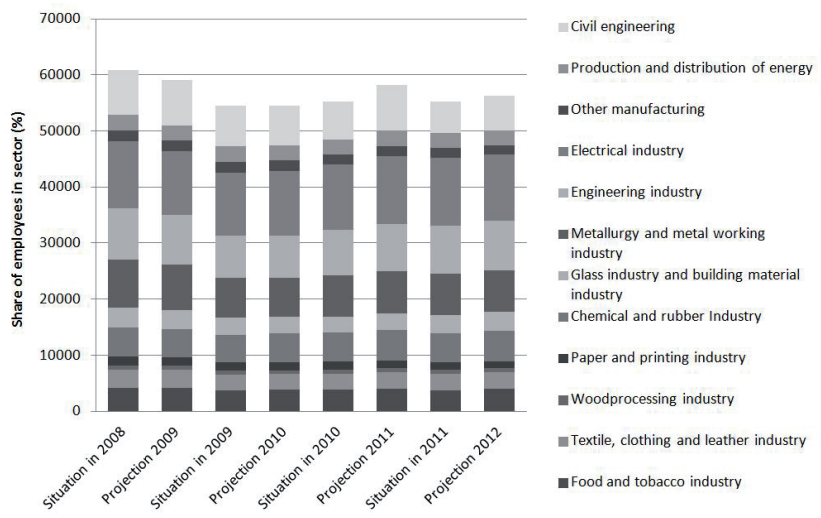

Fig. 5 - Real number of employees in enterprises of the secondary sector of the national economy as at 31/12/2008 2011 and expected number as at 31/12/2009-2012. Source: Questionnaire survey of the Labour Offices in the South Moravian Region for the years 2008-2011, own elaboration 
The results of the survey of employment in the South Moravian region can be compared with the business cycle research (tab. 2), which, among other things, also studied trends in the number of employees in the processing industry enterprises in the Czech Republic and expectations for the development in 2012. Business cycle survey respondents expected deterioration in the manufacturing activity and employment for the first three months of 2012. Contrary to the situation in the period of the survey (December 2011), they expect a decline in employment in the next three months by $12.9 \%$. Stagnation or growth is not expected in the enterprises. Even in the next months of 2012, the enterprises do not expect growth in the number of employees.

Tab. 2 - Development expected in the enterprises from January to March 2012 by size classes, according to the survey of employment in the South Moravian Region and the business cycle survey. Source: Questionnaire survey of the Labour Offices in the South Moravian Region as at 31/12/2012; Business Cycle Survey in the industry enterprises. CSO Prague, 2012

\begin{tabular}{|c|c|c|c|c|c|c|c|c|}
\hline \multirow[b]{3}{*}{$\begin{array}{l}\text { Number of } \\
\text { employees }\end{array}$} & \multicolumn{8}{|c|}{ Index in $\%$, by the number of employees } \\
\hline & \multicolumn{4}{|c|}{ Survey of employment } & \multicolumn{4}{|c|}{ Business Cycle Survey } \\
\hline & 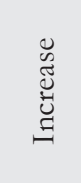 & 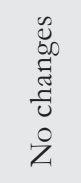 & 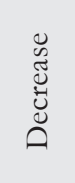 & $\begin{array}{c}\text { Balance } \\
(+/-)\end{array}$ & 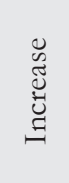 & $\begin{array}{l}\tilde{D} \\
\dot{0} \\
\text { I } \\
\tilde{U} \\
0 \\
0 \\
Z\end{array}$ & 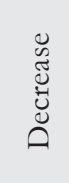 & $\begin{array}{c}\text { Balance } \\
(+/-)\end{array}$ \\
\hline $1-99$ & 29,9 & 56,4 & 13,6 & $+2,1$ & 4,3 & 75,9 & 19,8 & $-15,5$ \\
\hline $100-299$ & 48,0 & 30,4 & 21,6 & $+4,6$ & 6,7 & 73,8 & 19,5 & $-12,8$ \\
\hline $300-499$ & 42,6 & 21,4 & 35,7 & $-1,2$ & 6,6 & 72,2 & 21,2 & $-14,6$ \\
\hline $500-999$ & 58,3 & 0,0 & 41,7 & $+0,2$ & 7,9 & 64,6 & 27,5 & $-19,6$ \\
\hline $1000-1999$ & 50,0 & 0,0 & 50,0 & $-1,2$ & 6,9 & 68,0 & 25,1 & $-18,2$ \\
\hline $2000-4999$ & 100,0 & 0,0 & 0,0 & $+0,8$ & 0,0 & 76,8 & 23,2 & $-23,2$ \\
\hline $\begin{array}{c}5000 \text { and } \\
\text { more }\end{array}$ & - & - & - & - & 33,3 & 27,4 & 39,3 & $-6,0$ \\
\hline In total & 35,0 & 48,0 & 17,0 & $+5,3$ & 9,9 & 67,3 & 22,8 & $-12,9$ \\
\hline
\end{tabular}

Different results of the survey of employment and the business cycle survey may be caused by the spatial level. While the diversified industry can get stronger in the region, at the national level there can be further decline in employment in the industry and strengthening in services (fig. 6). 


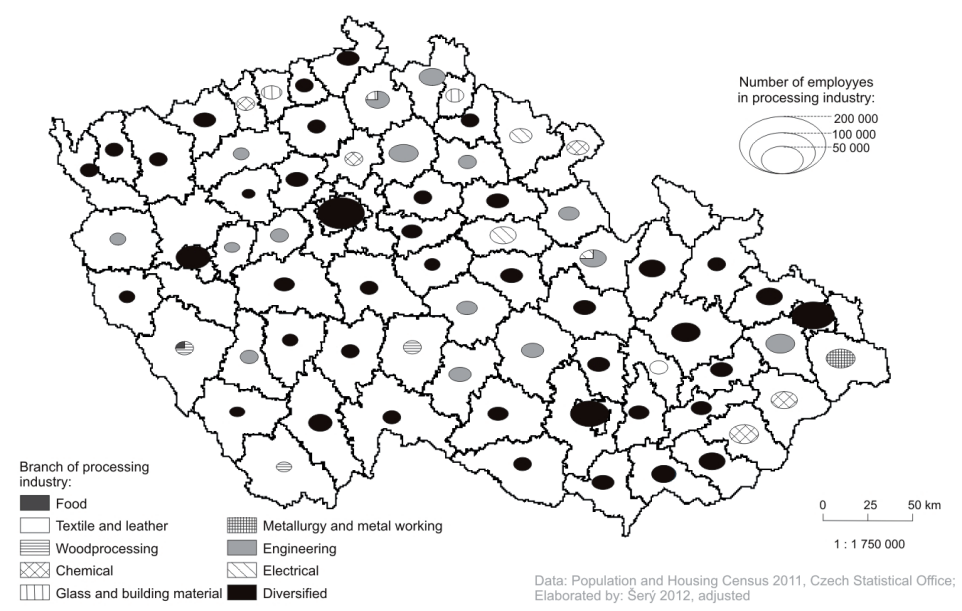

Fig. 6 - Typology of districts of the Czech Republic by the specialization of the processing industry as at 26/3/2011. Source: Śrý (2012)

There is demand and supply for individual employees' professions associated with the changes in the labour market. Also hiring and dismissing employees are in accordance with the development of the number of employees in different sectors. While during the year 2009 (i.e. when the economic recession escalated most) especially unprofessional staff were dismissed (in electronics, engineering, etc.), in 2010 and 2011, the demand just for these workers increased (Vnoučková 2012), which may be another evidence of the subsiding recession and the recovery of production in industrial enterprises. The demand for specialized crafts (metalworking, machinery engineering ...) increased, too - see tab. 3.

Tab. 3 - TOP 10 professions most demanded in the time of the survey of employment as at $31 / 12 / 2010$ and 31/12/2011, and 10 professions where reduction of the number of workers was planned. Source: Survey of the employment in the South Moravian Region as at 31/12/2011

\begin{tabular}{|c|c|c|c|}
\hline \multirow{2}{*}{2010} & Reduction & Increase \\
\hline Reduction & Metalworking ma- & Electrical equipment \\
chines operators & $\begin{array}{c}\text { Metalworking } \\
\text { assembly workers } \\
\text { manes fixers and } \\
\text { operators }\end{array}$ \\
\hline Security guards & $\begin{array}{c}\text { Construction work- } \\
\text { ers }\end{array}$ & Shop assistants & $\begin{array}{c}\text { Agriculture special- } \\
\text { ists }\end{array}$ \\
\hline Professional office \\
workers & $\begin{array}{c}\text { Toolmakers and } \\
\text { metal-workers }\end{array}$ & $\begin{array}{c}\text { High school and } \\
\text { upper primary school } \\
\text { teachers }\end{array}$ & Welders \\
\hline Accountants & Unskilled labourers & Office workers & $\begin{array}{c}\text { Metal processing } \\
\text { machines operators }\end{array}$ \\
\hline
\end{tabular}




\begin{tabular}{|c|c|c|c|}
\hline Unskilled labourers & Computer operators & $\begin{array}{c}\text { Security guards } \\
\text { and security agency } \\
\text { workers }\end{array}$ & Electrical engineers \\
\hline $\begin{array}{c}\text { Machine and equip- } \\
\text { ment operators }\end{array}$ & Nurses & Clerks & Software developers \\
\hline $\begin{array}{c}\text { Food machine opera- } \\
\text { tors }\end{array}$ & $\begin{array}{c}\text { Engineering techni- } \\
\text { cians }\end{array}$ & Electrical engineers & $\begin{array}{c}\text { Forklifts operators } \\
\text { and storekeepers }\end{array}$ \\
\hline $\begin{array}{c}\text { Truck drivers } \\
\text { bly workers }\end{array}$ & $\begin{array}{c}\text { Electrical engineers, } \\
\text { repairmen and fixers }\end{array}$ & $\begin{array}{c}\text { Forklifts operators } \\
\text { and storekeepers }\end{array}$ & $\begin{array}{c}\text { Masons, stove build- } \\
\text { ers, pavers }\end{array}$ \\
\hline $\begin{array}{c}\text { Construction assem- } \\
\text { ing workers }\end{array}$ & Physicians & $\begin{array}{c}\text { Mechanical device } \\
\text { assembly workers }\end{array}$ & $\begin{array}{c}\text { Mechanical device } \\
\text { assembly workers }\end{array}$ \\
\hline
\end{tabular}

\section{DISCUSSION}

Development in the labour market of the Czech Republic went through significant changes after 2008 , i.e. after beginning of the economic recession. Impacts of this recession are reflected in changes of the structure of employment and the unemployment rate, which showed a very positive trend in the period 2005-2008.

The economic recession also amplified some of the problems with which the labour market struggles for many years in regions of the country. There occurs particularly inefficient and very limited support for the regions with concentrated state support (in the South Moravian region, districts of Hodonín, Znojmo and Blansko are included), but also discrepancy between demand and supply of the structure of workers in the labour market, which has been being mentioned and still unsolved for a long time. This discrepancy concentrates workers of the tertiary sector, but lacks skilled workers in certain industries. Also Berzinskiene \& Juozaitiene (2011) confirm similar results: "the measure variety of labour market regulation and employment promotion exists and relatively relieves unemployment consequences, but does not decrease the rate of unemployment and often suppresses motivation to work."

Negative development in the labour market in the period 2008-2010 (when the expectations of enterprises in terms of the development of employment in the primary sector were even worse than the original premises and completely fulfilled in the secondary and tertiary sector) were replaced by more optimistic expectations of the development at the end of 2010 - together with a slight recovery of production, a number of companies expect hiring workers, or at least no other layoffs. Development in 2011 can be regarded as positive, partly due to decline in the unemployment rate, partly due to the optimism of enterprises in the South Moravian Region. The number of vacancies, however, did not grow and there is still a crowd of applicants for vacancies. At the national level, the expectations seem to be much worse - firms in the manufacturing industry intend to continue in layoffs and reduce their production. So, the first part of the defined hypotheses is not completely fulfilled. 
The second part of the hypothesis is true - between the years 2008 and 2010 there was the biggest attenuation in the textile, clothing and leather industry, food industry, glass industry and building materials industry, i.e. in sectors with less skilled labour force. In contrast, the lowest decline was in the wood processing industry and the chemical and rubber industry.

\section{CONCLUSION}

The situation in the labour market in the South Moravian Region and the Czech Republic, however, does not develop in isolation and also responds to the economic situation in the neighbouring countries (mainly in Germany, the Czech Republic's export leader). However, the situation of the Czech economy and thus the development of the labour market are still not stable and are very sensitive to any changes occurring in foreign (international) markets. The euro zone crisis and the economic problems of some EU states have significant influence, too. It is needed to react quickly to them, and not only by continuous evaluation and analysing the situation, but mainly by formulation and implementation of appropriate measures.

Survey of employment in the South Moravian Region is a document that reveals the internal structure of enterprises and employment, and enables to formulate appropriate action affecting the situation in the labour market, which can be realized by the South Moravian Region itself. The most important support is expected mainly from the central level, from the newly established Labour Office of the Czech Republic, through active employment policy, which is not working too well now (and the Labour Office of the Czech Republic is also struggling with its internal problems), as well as through the implementation of measures and activities formulated in variety of strategic and conceptual documents at the regional and national level.

\section{References}

1. Akyüz, Y. (2011). Global Economic Prospects: The Recession May be Over but Where Next? Global Policy, 2(2), 127-137. http://dx.doi.org/10.1111/j.1758-5899.2010.00074.x

2. Barakat, B., Holler, J., Prettner, K. \& Schuster, J. (2010). The Impact of the Economic Crisis on Labour and Education in Europe Vienna: Vienna Institute of Demography. Retrieved from http://ideas.repec.org/p/vid/wpaper/1006.html

3. Berzinskiene, D. \& Juozaitiene, L. (2011). Impact of Labour Market Measures on Unemployment. Inzinerine ekonomika-Engineering economics, 22(2), 186-195.

4. Broersma, L. \& van Dijk, J. (2002). Regional labour market dynamics in the Netherlands. Papers in Regional Science, 81(3), 343-364. http://dx.doi.org/10.1007/s101100200126

5. Chowdhury, A., Islam, I. \& Lee, D. (2013). The Great Recession, jobs and social crises: Policies matter. International Journal of Social Economics, 40(3), 220-245. http://dx.doi. org/10.1108/03068291311291518

6. Czech Statistical Office (2011). Dopady světové finanční a hospodářské krize na ekonomiku ČR. Retrieved from http://www.stredocesky.czso.cz/csu/ 2010edicniplan. nsf/t/0F00528391/\$File/ 11561010.pdf

7. Domínguez-Mujica, J., Guerra-Talavera, R. \& Parreño-Castellano J. M. (2012). Migration at a Time of Global Economic Crisis: The Situation in Spain. International Migration. http:// dx.doi.org/10.1111/imig.12023 
8. Fang, C., Dewen, W. \& Yang, D. (2002). Regional disparity and economic growth in China: The impact of labor market distortions China. Economic Review, 13(2-3), 197-212. http:// dx.doi.org/10.1016/S1043-951X(02)00072-X

9. Fikret, C. (2012). What type of fiscal policy for the Western Balkans during the crisis. Southeast European and Black Sea Studies, 12(2), 357-372. http://dx.doi.org/10.1080/14683857. 2012.686017

10. Fišer, P., Toušek, V. \& Janota, M. (2008). Changes in employment structure in the Czech Republic influenced by the transformation of economy. Wroclaw: Institute of Geography and Regional Development, Univerzity of Wroclaw.

11. Gora, M. \& Lehmann, H. (1995). How divergent is regional labour market adjustment in Poland? München: Ifo-Institut für Wirtschaftsforschung.

12. Klinger, S. \& Rothe T. (2010). The impact of labour market reforms and economic performance on the matching of short-term and long-term unemployed. IAB Discussion Paper. Nuremberg: Institute for Employment Research of the Federal Employment Agency. Retrieved from http://doku.iab.de/discussionpapers/2010/dp1310.pdf

13. Konjunkturální průzkum v průmyslových podnicích (2010). Praha: Czech Statistical Office. Retrieved from http://www.czso.cz/csu/2010edicniplan.nsf/ publ/1201-10prosinec_2010

14. Kunc, J. \& Toušek, V. (2001). In: Slaný, A. (ed.): Česká ekonomika na přelomu tisíciletí (pp. 515-530). Brno: Masarykova univerzita. Ekonomicko-správní fakulta.

15. Lauko, V., Križan, F. \& Gurňák, D. (2009). Časovo-priestorové aspekty nezamestnanosti na Slovensku v procese ekonomickej transformácie a krízy. In Klímová, V. (Ed.), Sborník příspěvků XII. mezinárodní kolokvium o regionálních vědách (pp. 58-65). Brno: Masarykova univerzita.

16. Leschke, J. \& Watt, A. (2010). How do institutions affect the labour market adjustment to the economic crisis in different EU countries? European Trade Union Institute Working Paper 2010(04), Brussels: ETUI aisbl. Retrieved from http://www.global-labour-university.org/ fileadmin/GLU_conference_2010/papers/ 36._How_do_institutions_affect_the_labour_ market_adjustment_to_the_economic_crisis_in_different_EU_countries.pdf

17. Maryáš, J., Řehák, S. \& Szczyrba, Z. (2006). Prostorově funkční transformace sektoru služeb v Česku - vývoj po roce 1989. In Kraft, S, Mičková, K., Vančura, M., Veselá, H. (Eds.). Česká geografie v evropském prostoru. České Budějovice: Jihočeská univerzita. .

18. Ministerstvo práce a sociální věcí - Integrovaný portál MPSV. Retrieved from portal.mpsv. $\mathrm{CZ}$

19. Národní účty (2008-2011). Czech Statistical Office. Retrieved from http://www.czso. cz/csu/csu.nsf/kalendar/2010-hdp

20. Pavlínek, P. \& Ženka, J. (2010). The 2008-2009 automotive industry crisis and regional unemployment in Central Europe. Cambridge Journal of Regions, Economy and Society, 3(3), 349-365. http://dx.doi.org/10.1093/cjres/rsq026

21. Rojíček, M. (2010). Dopady ekonomické krize na nabídkovou stranu ekonomiky. Ekonomické listy, 2010(3), 3-13.

22. Šerý, O. (2012). Zaměstnanost v České republice: hodnocení změn odvětvové a vzdělanostní struktury (s využitím předběžných výsledků sčítání lidu 2011). Brno: Geografický ústav PřF MU. 
23. Singer, M. (2011). Finanční krize a ekonomika, výhled do budoucna. Retrieved from http:// www.cnb.cz/miranda2/export/sites/www.cnb.cz/cs/verejnost/pro_media/ konference_ projevy/vystoupeni_projevy/download/singer_20110303_pojistovna_cs.pdf

24. Smith, A. \& Swain, A. (2010). The Global Economic Crisis, Eastern Europe, and the Former Soviet Union: Models of Development and the Contradictions of Internationalization. Eurasian Geography and Economics, 51(1), 1-34. http://dx.doi. org/10.2747/1539-7216.51.1.1

25. Svobodová, H., et al. (2011). Průzkum zaměstnanosti v Jihomoravském kraji k 31. 12. 2010. Brno: GaREP.

26. Szczyrba, Z., Toušek, V. \& Maryáš, J. (2005). Procesy transformacyjne w handlu detalicznym Republiki Czeskiej w układzie regionalnym. Kosiedowski, W. (Ed.): Regiony Europy Środkowej i Wschodniej wobec glogalizacji i integracji międzynarodowej (pp. 409-412). Toruń: Uniwersytet Mikołaja Kopernika..

27. Toušek, V. et al. (2009). Současný stav a vývojové trendy trhu práce v Jihomoravském kraji a srovnání s regiony ČR a EU. Brno: Jihomoravský kraj.

28. Toušek, V. \& Novák, V. (2010). Labour Market in the Czech Republic during the Present Economic Crisis. Acta Universitatis Palackianae Olomucensis, 41(2), 65-80.

29. Varum, C. A. \& Barros Rocha, V. C. (2011) Do foreign and domestic firms behave any different during economic slowdowns? International Business Review, 20(1), 48-59. http:// dx.doi.org/10.1016/j.ibusrev.2010.06.001

30. Viturka, M. et al. (2000). Geographical Aspects of Industrial Transformation in the Czech Republic. Geografie, 105(2), 155-165.

31. Vnoučková, L. (2012). Monitoring of Labour Mobility as a Way to Competitiveness. Journal of Competitiveness, 4(3), 105-121. http://dx.doi.org/10.7441/joc.2012.03.08

32. Výběrové šetření pracovních sil za 4. čtvrtletí roku 2010 (2011). Czech Statistical Office. Retrieved from http://www.czso.cz/csu/2011edicniplan.nsf/p/3115-11

\section{Contact information}

dr. Hana Svobodová

Masaryk University, Faculty of Education, Department of Geography

Poricici 7, 60300 Brno, Crech Republic

E-mail: hsvobodova@ped.muni.cr.

JEL Classification: J21 